\title{
Clay Detection in Lakes of Latgale Using Ground Penetrating Radar
}

\author{
Rasma Tretjakova \\ Rezekne Academy of Technologies \\ Rezekne, Latvia \\ rasma.tretjakova@rta.lv \\ Aigars Alksnis \\ Institute for Environmental Solutions \\ Riga, Latvia \\ aidzhers@inbox.lv
}

\author{
Sergejs Kodors \\ Rezekne Academy of Technologies \\ Rezekne, Latvia \\ sergejs.kodors@rta.lv
}

\author{
Juris Soms \\ Daugavpils University \\ Daugavpils, Latvia \\ juris.soms@du.lv
}

\begin{abstract}
The most common method to determine the presence of clay in lakebed is coring method. This method requires survey of the whole lake area using stratified sampling method which is time and physical labour consuming process. To lessen the amount of coring samples and narrow the area of clay survey thus making the whole process faster and more effective, research was made to determine the possibility to indentify clay and its sediments using georadar survey or ground penetrating radar (GPR) method. GPR data analysis and coring studies in lake Zeilu were used to evaluate GPR as potential method in lake clay sediment research. GPR method was tested in summer and winter during ice-covered period.
\end{abstract}

Keywords—clay, ground penetrating radar, Latgale lakes

\section{INTRODUCTION}

According to data of Latvian Institute of Amelioration obtained in 1970-ies, in Latvia there are 2256 lakes with a total area of approximately 100000 hectares, with the water surface area being larger than or equal to 1 hectare. Only 124 of these are larger than 100 hectares. Most of the lakes are located in the uplands, with a great many being in South-eastern Latvia - in the Latgale Upland [1]. That sparks interest of scientific level in terms of industrial application of lake resources.

Lake Plusons research [2] identified clay sediments, clay was located in lake Zeiļu as well. Lake sediment survey is a complicated process that consumes both time and money. Moreover, samples obtained manually provide poor survey area data. Considering this, remote sensory methods provide thorough data about survey region and cost less.

Nowadays geophysical methods for sedimentological analysis of waterbodies are being used more often than traditional methods (e.g., coring and trenching) [3]. Ground penetrating radar technology is nondestructive method that uses electromagnetic radiation in the microwave band (UHF/VHF frequencies) of the radio spectrum, and detects the reflected signals from subsurface structures. The depth range of GPR is limited by the electrical conductivity of the ground, the transmitted center frequency and the radiated power. GPR has been used successfully to aid in geophysical mapping of shallow subsurfaces and constraining problems in diverse fields such as archaeology, environmental site characterization and engineering, glaciology, hydrology, landmine/ unexploded ordnance detection, sedimentology, and structural geology. It can also be applied in groundwater and mineral exploration, forensic investigations and depth soundings through ice or water [3] - [5]. Many researches carried out using georadiolocation method in Latvia and Europe have proven its effectivity and ability to survey waterbodies [6] - [12].

The research goal is to evaluate the ground penetrating radar method data in order to detect clay sediments and their distribution in lakebed.

\section{Material AND Methods}

The ground penetrating radar (GPR) signals could penetrate through fresh water into bottom sediments and hence provide information about geological structure [7], [13]. In addition, the advantage of GPR survey is possibility to obtain a continuous cross-sectional profile or record of subsurface features along the survey line [8], [9]. Hence the application of GPR survey was performed in lake Zeily with purpose to test the possibility of clay deposits identification by this shallow geophysical method. The lake is located in the north-western part of Isnaudas rural municipality, Ludzas region, $3 \mathrm{~km}$ southwest from Ludza town. The lake embeds in gentle terrain lowering situated in the Rēzekne depression, north-eastern part of the Latgale Upland. The altitude of its water surface is $134.6 \mathrm{~m}$ asl. The lake Zeilu, considering its trophic state, is eutrophic lake with thick layer of bottom sediments, its water surface is almost entirely covered by macrophyte vegetation. The total area of lake is 44.8 ha, its average depth is $1.1 \mathrm{~m}$ and maximum depth is $1.6 \mathrm{~m} \mathrm{[14].}$

The GPR Zond 12-e Advanced, manufactured in Latvia by Radar Systems, was employed for the georadar profiling. A portable GETAC computer connected to the control unit allows the direct recording of geophysical raw data and preliminary visualization and monitoring

Print ISSN 1691-5402

Online ISSN 2256-070X

http://dx.doi.org/10.17770/etr2019vol1.4046

(C) 2019 Rasma Tretjakova, Sergejs Kodors, Juris Soms, Aigars Alksnis. Published by Rezekne Academy of Technologies.

This is an open access article under the Creative Commons Attribution 4.0 International License. 
of profiles in situ. The alternate application of three transmission frequencies, using shielded $500 \mathrm{MHz}$ and $300 \mathrm{MHz}$ antennas, as well unshielded $75 \mathrm{MHz}$ antennae, was tested to elucidate the best recognition of boundary between lake bottom sediments and bedrock. The data obtained in the course of GPR survey were post-processed and analysed by software Prism 2.60. Processing included the using of time-dependent signal gain function, removing of background signal and application of band-pass filter. GPR profiling was performed on the ice-covered lake in March 16, 2018 and on inflatable boat in June 8, 2018 (Fig. 1).

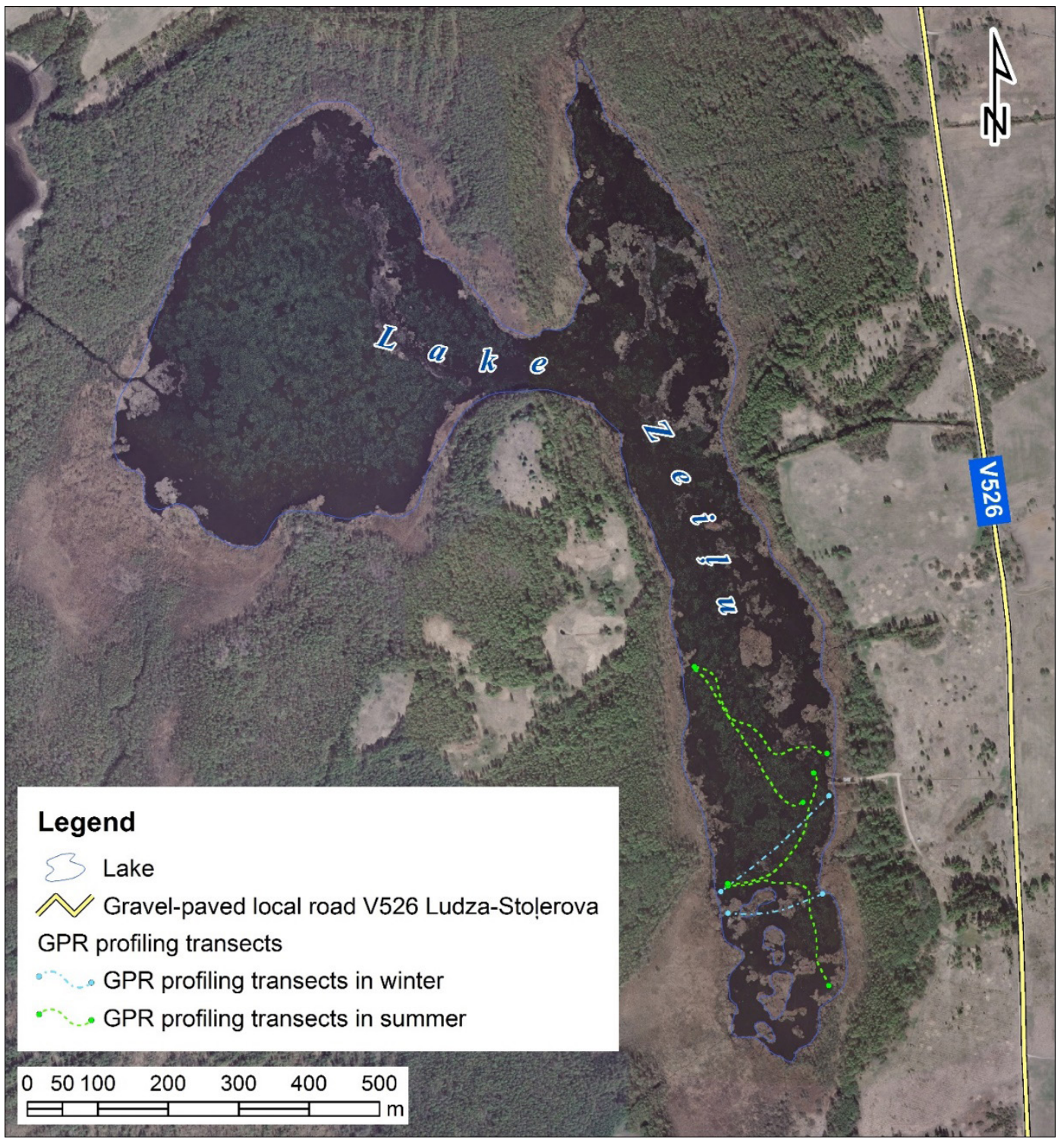

Fig. 1. GPR measurement lines lake Zeiļu in March 16, 2018 and June 8, 2018

GPR profiling transects for survey in winter, i.e. ice cover period were selected in such a way as to coincide with points where sampling of clay sediment layers in the lake was realised previously. It allows to compare results obtained by conventional geological methods and by geophysical methods. Profiling transects were marked as two lines by several $100 \mathrm{~m}$-long measurement fibreglass tapes. The GPR data was acquired by moving the georadar system along these profiling lines. For the each of applied antennae system GPR profiles were obtained in the course of toward and backward survey along the same transect, subsequently aggregating these measurements into one GPR radargram by software. Besides the using of tapes for marking and measuring of profiles, the length and trajectories of GPR survey lines were fixed by electronic odometer. It allowed to record the position of GPR on the profile and the received signal in the memory of GPR control unit.
Considering that resolution of details recognizable in GPR radargram is proportional to the transmitted frequency of antennae [11], [15], theoretically, the most detailed information about the lake bottom sediment structure could be obtained by using the $500 \mathrm{MHz}$ antennae system. However, due to frequency dependent attenuation and dissipation of electromagnetic waves, GPR signal of such frequency do not penetrate deep enough, allowing to obtain the data only from small depths. Hence antennas with a lower frequency $(300 \mathrm{MHz}$ and $75 \mathrm{MHz}$ ) were also applied for ensuring deeper penetration, but these antennas provided less resolution in GPR radargrams.

During the ice-free period GPR survey was performed in the southern part of lake Zeilu, placing antennas on the bottom of a inflatable rubber boat. The dense cover of macrophyte vegetation did not allow to make regular net of GPR profiles, therefore survey lines were chosen 
in places with less vegetation density. The length and trajectories of GPR survey lines were fixed by GPS, the location of GPR measurement lines is shown in Fig. 1.

\section{Results And Discussions}

In the processed GPR profile obtained by geophysical survey with $500 \mathrm{MHz}$ antennae from the lake ice radargram show several strong reflections as horizontal lateral continuity (Fig. 2). This argues for echoes signals or reverberations of the electromagnetic waves within ice cover rather than true signal penetration in water and bottom sediments. This observation can be associated to reverberations of GPR signal in the lake ice caused by the high dielectric contrast between the ice cover in the lake (relative permittivity $\varepsilon_{r}=3-4$ ) and the freshwater underneath the ice $\left(\varepsilon_{r}=81\right)$ [15]. The strong reverberations mask the signals from deeper reflections thus making the detection of informative signal impossible. In the upper part of the processed GPR profile obtained by geophysical survey with $300 \mathrm{MHz}$ antennae from the lake ice three main types of GPR signal reflections can be identified: 1) horizontal continuous lines; 2) parabolic curves and 3) horizontal wavelet successions (Fig. 3.). The first type, i.e. horizontal reflections well-expressed in radargram, like the ones obtained by $500 \mathrm{MHz}$ antennae, indicates the reverberations of GPR signal in the lake ice. The second type of reflections (sections 1-2; 3-4 and 5-6 in the Fig. 3 ) indicates the presence of material with a significant difference in the dielectric transmittance, which creates a parabolic reflection of the georadar signal. In this case such parabolic curves are attributed to small rises of lake bottom or shallows located near to the surface of lake. These features were identified also in the field during the GPR survey thanks to presence of Salix $s p$. bush patches, and appropriately marked in the georadar profile for the later interpretation of data. The horizontal wavelet successions depict the reflected arrivals of GPR signal within the lake water rather than reflections arose from real bottom sediment boundaries. Due to the strong attenuation of electromagnetic waves by clay sediments, the reflections from deeper layers have low intensity, hence avoiding the receiving of informative signal from the boundary between clay sediments and the lake bedrock surface.

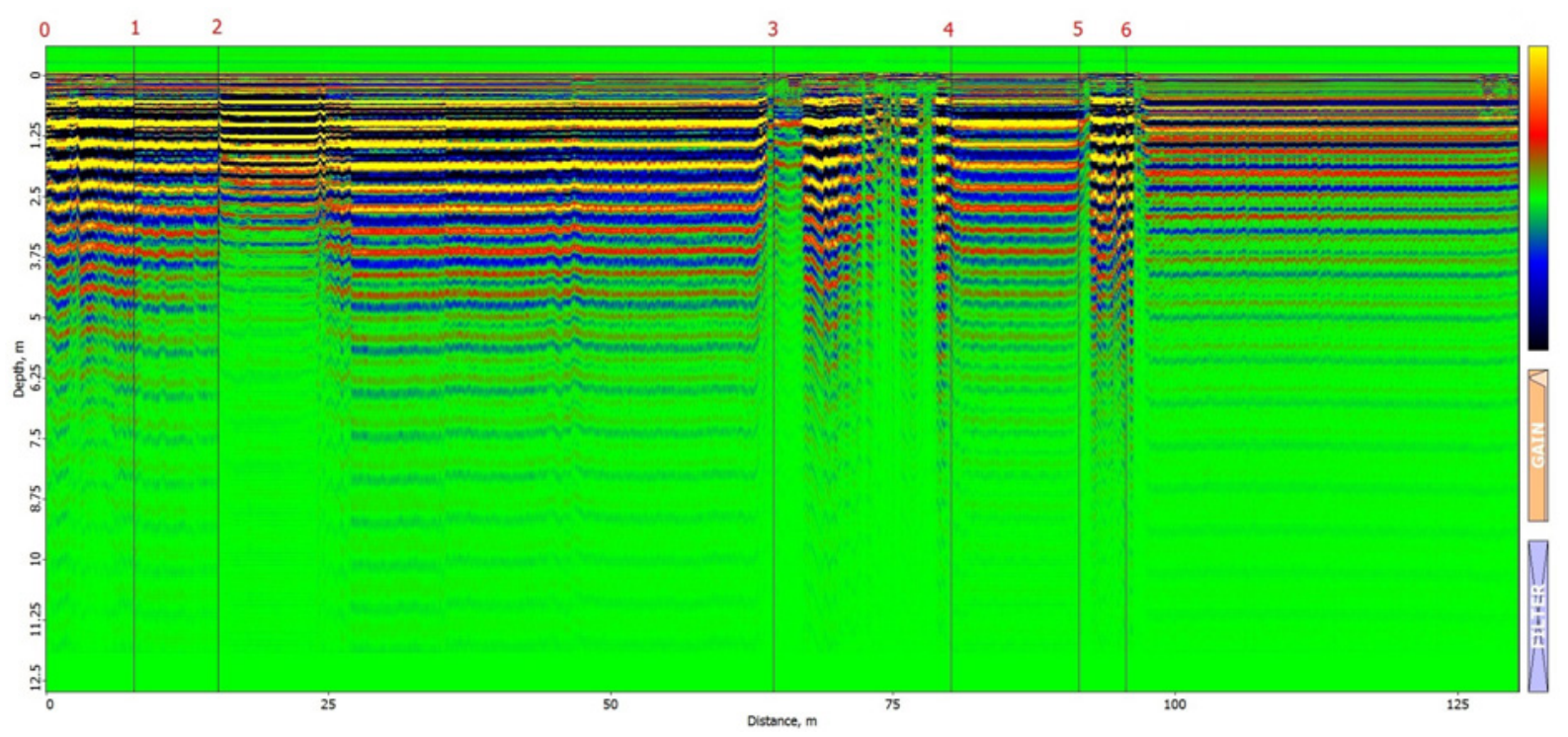

Fig. 2. Radargram showing GPR profile obtained by geophysical survey with $500 \mathrm{MHz}$ antennae from the ice surface

In the processed GPR profile obtained by geophysical survey with unshielded $75 \mathrm{MHz}$ antennae from the lake ice, the bottom of the lake can be identified at the depths from 1 to $1.75 \mathrm{~m}$ (white dashed line in Fig.4), associated with high dielectric contrast between the water and bottom sediments. However, due to low vertical resolution of antennae frequency used, the obtained quality of GPR profile is poor. At the same time, as it is aforementioned, strong attenuation of electromagnetic waves by clay sediments constituting bottom sediments avoid the receiving of informative signal and the detection of the clay layers thickness.

Hence in the course of GPR survey during the ice cover period none of applied antenna system provide adequate geophysical data, on the basis of which georadar could be used as method for identification of clay deposits in lake Zeilu. It can be explained first of all, by thick double-layered ice cover (winter ice and spring frost ice, and layer of thawed water between them), which generates strong reverberation of GPR signal and consequently masking and attenuating informative reflections from deeper media. Secondly, despite the well-recognized fact that fresh water has relatively low attenuation of electromagnetic waves transmitted by GPR antennas, the presence of dissolved solids, as well fine suspended particles, particularly clay minerals particles in the water increase attenuation, causing a strong reduction in depth penetration. This assumption corresponds to data given in scientific literature. Although fresh water has relatively low attenuation, the presence of suspended sediments in the water will increase attenuation, causing a reduction in depth penetration [3]. Together these above mentioned factors favour very strong attenuation of GPR signal, avoiding the receiving of reflections suitable for qualitative visual interpretation and making GPR-based assessments unreliable. 


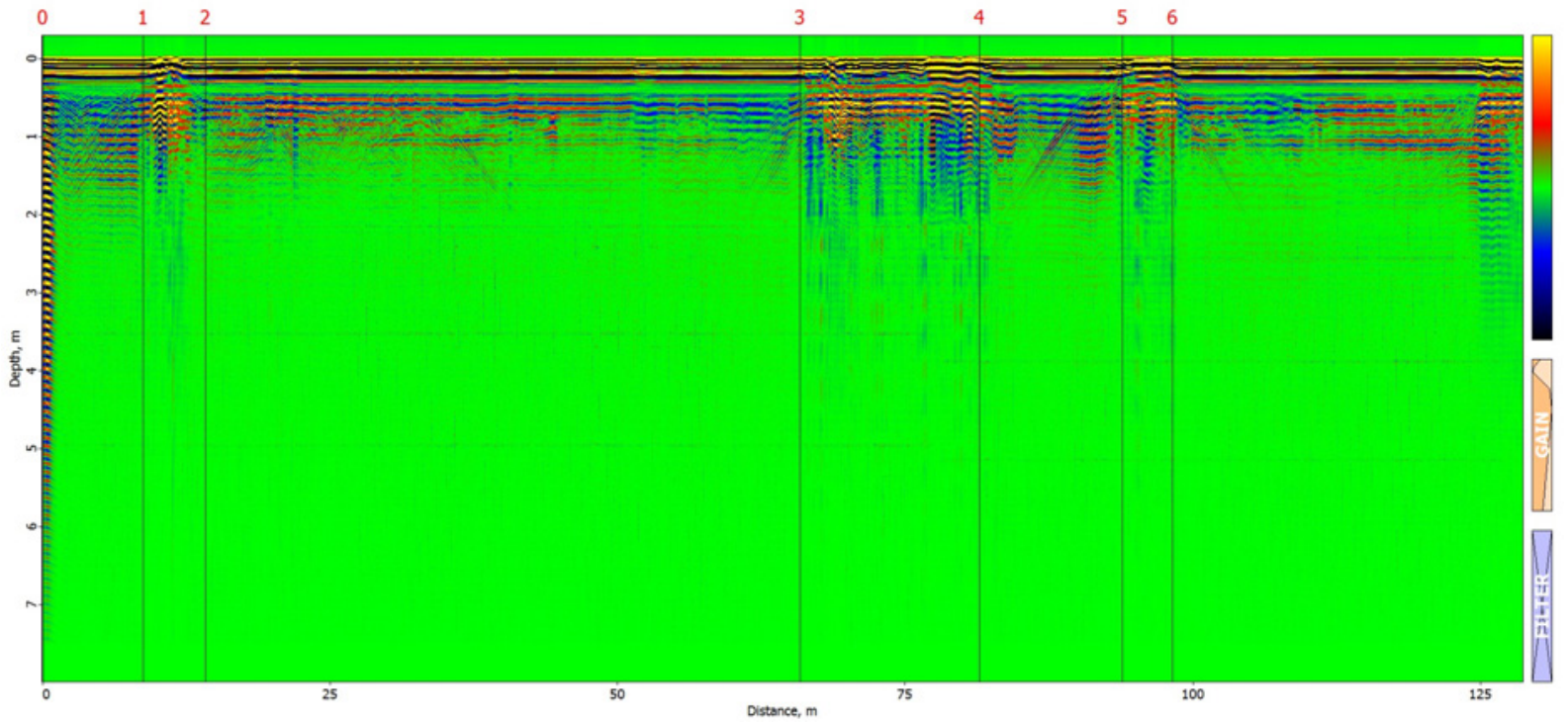

Fig. 3. Radargram showing GPR profile obtained by geophysical survey with $300 \mathrm{MHz}$ antennae from the ice surface

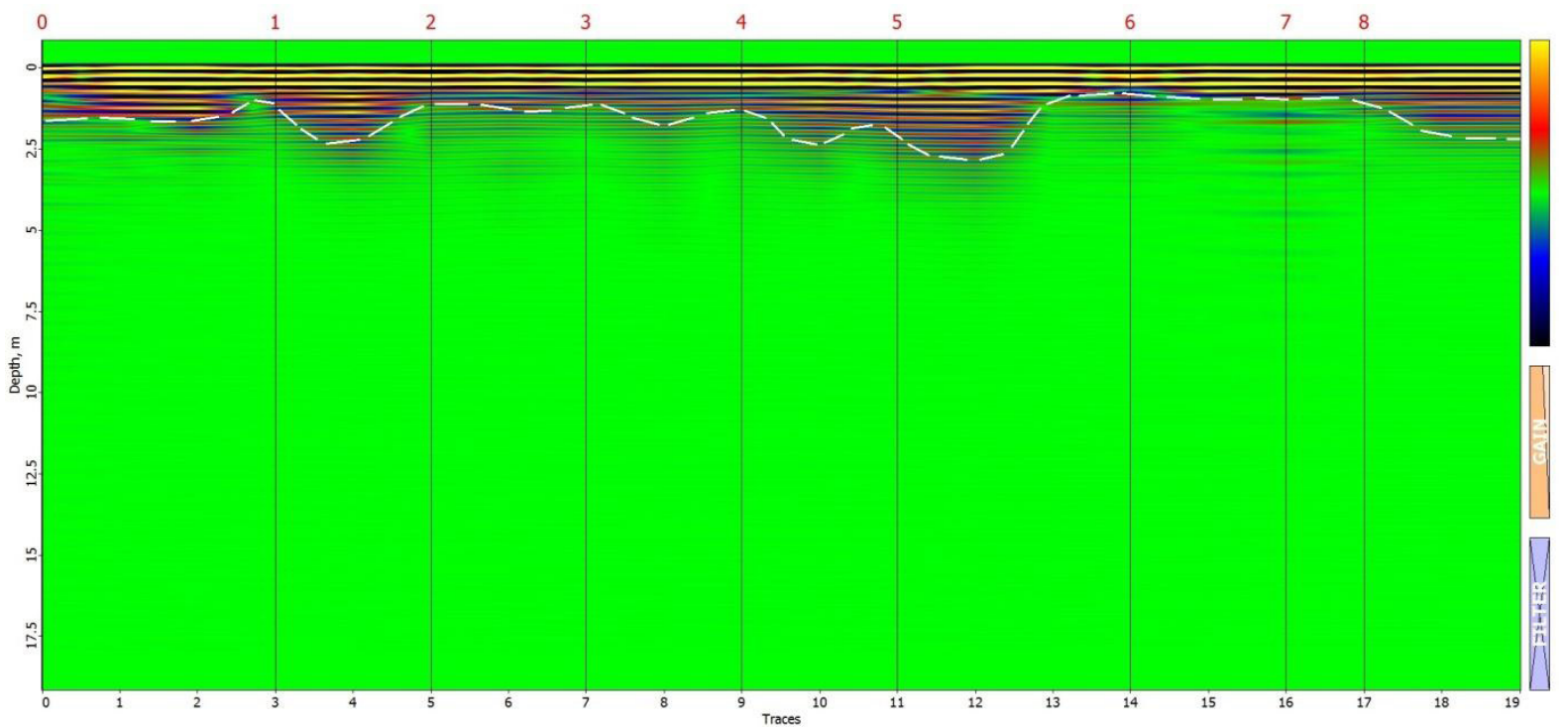

Fig. 4. Radargram showing GPR profile obtained by geophysical survey with $75 \mathrm{MHz}$ antennae from the ice surface

In the processed GPR profile obtained by geophysical survey with $500 \mathrm{MHz}$ antennae from the inflatable boat during summer period radargram show several strong reflections as horizontal lateral continuity and numerous overlapping parabolic curves below horizontal reflections (Fig. 5). The horizontal reflection is caused by sharp physical boundary between two media - air and water with high dielectric contrast between both of them. The parabolic reflections at depth about $1 \mathrm{~m}$ indicate the dense cover of submerged macrophyte plant vegetation.

The GPR profiles of the four transects obtained in the course of geophysical survey in summer period are displayed in Figs. 6 - 9. These profiles were additionally processed, using software tools for background signal removing, signal normalization and band-pass filtering. In this case, too, it can be seen reflections of objects at depth $\sim 1 \mathrm{~m}$, which according to the field observations, relate to submerged plant cover. The received signal from deeper layers is not strong enough, to distinguish the reflections from bottom sediments and noise. The assessment of geophysical data obtained during the summer period allow to establish, that lake Zeilu is not appropriate for detection of thickness of bottom sediment layers by application of GPR survey. The factors, which limit using of georadar for this purpose, could be high density of submerged and underwater macrophytes, e.g. yellow water-lily, water smartweed, elodea etc. The submerged and underwater macrophytes generate multiple reflections at relative small depths $(\sim 1 \mathrm{~m})$ and attenuate GPR signal. In addition, physical-chemical properties, i.e. high concentration of suspended sediments in water enhances attenuation of electromagnetic waves, causing a strong reduction in penetration of transmitted GPR signal by increasing of depth. 

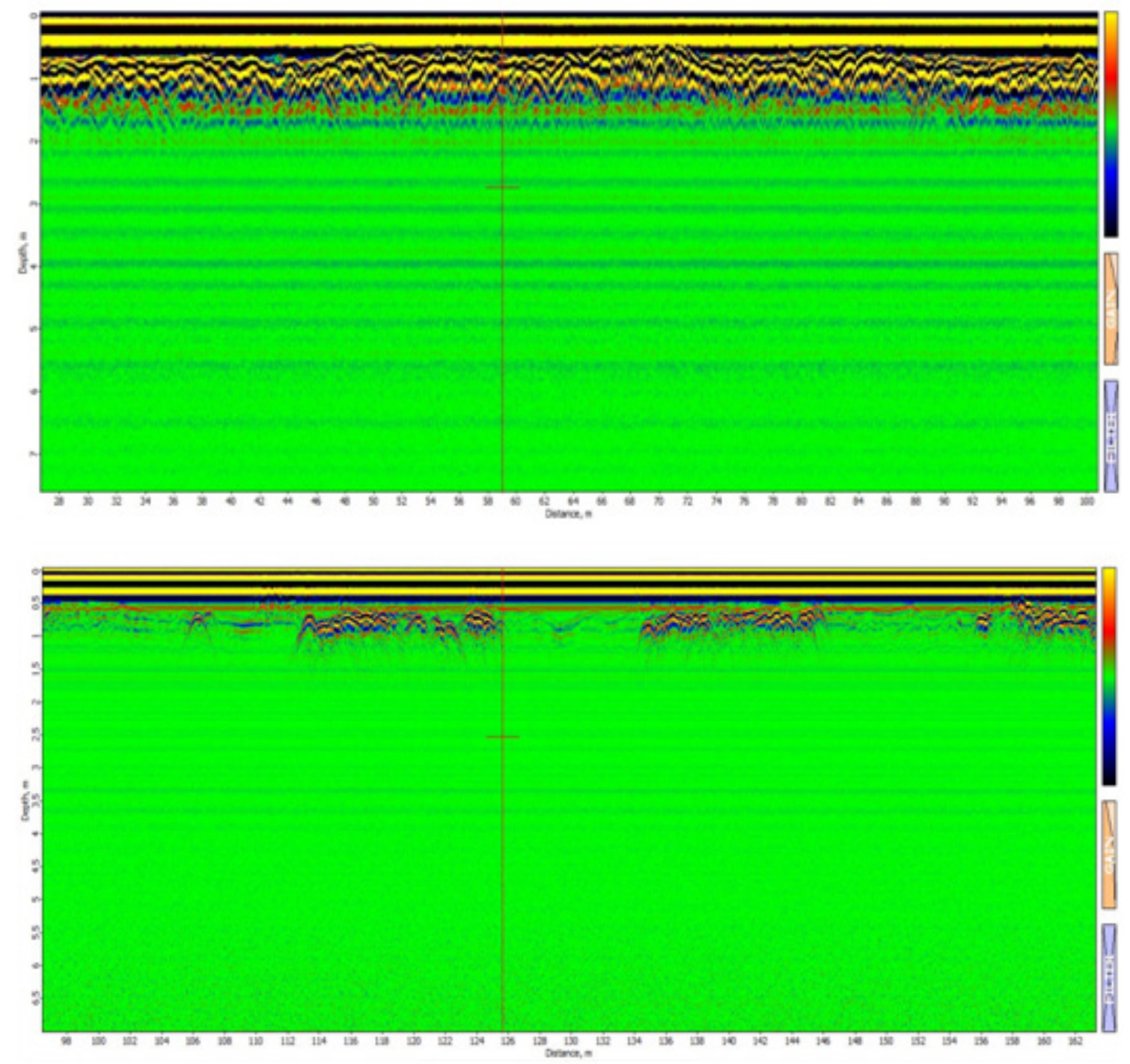

Fig. 5. Two radargrams showing GPR profiles obtained by geophysical survey with $500 \mathrm{MHz}$ antennae from the inflatable boat

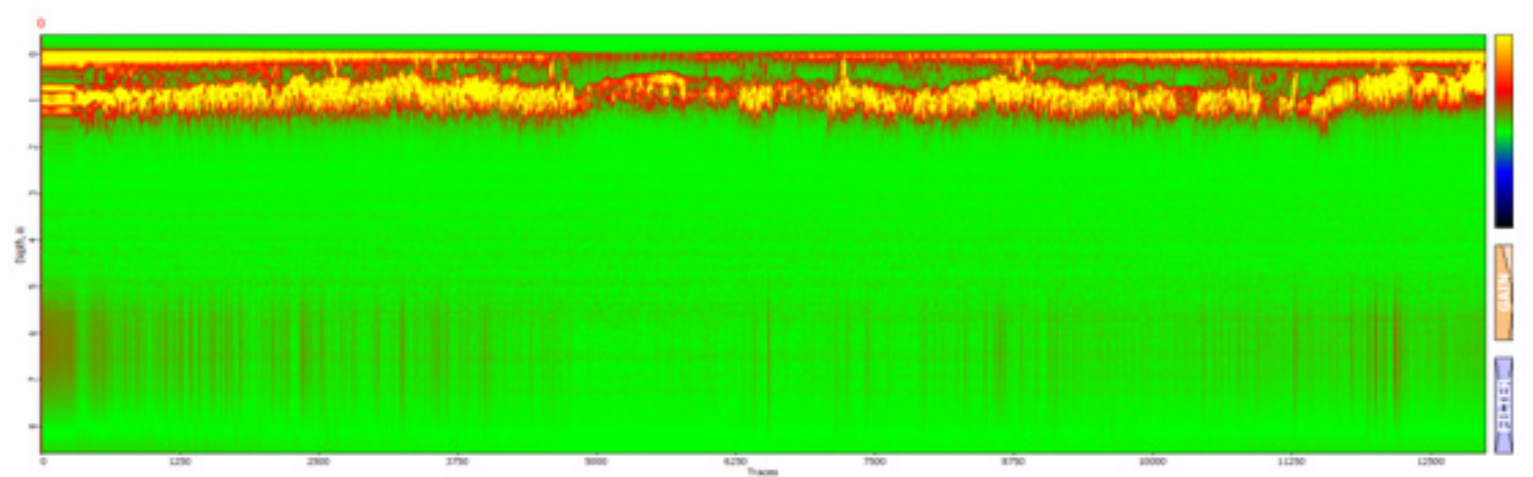

Fig. 6. Processed GPR profile obtained by geophysical survey with $500 \mathrm{MHz}$ antennae from the inflatable boat along the transect No.1 in lake Zeiļu 


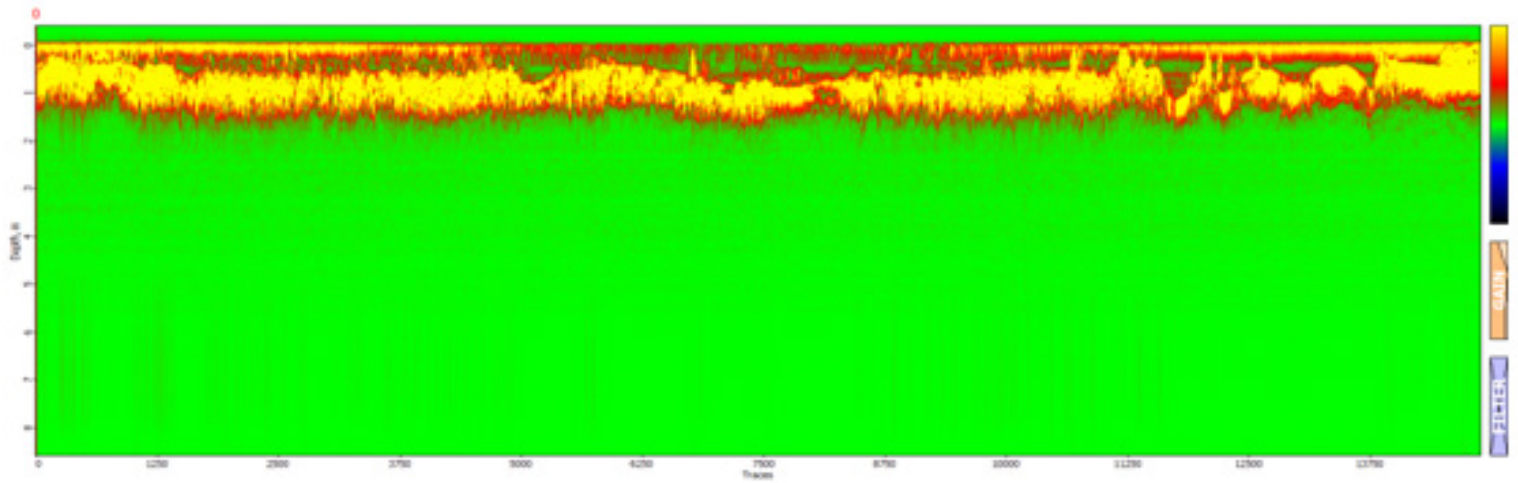

Fig. 7. Processed GPR profile obtained by geophysical survey with $500 \mathrm{MHz}$ antennae from the inflatable boat along the transect No.2 in lake Zeiļu

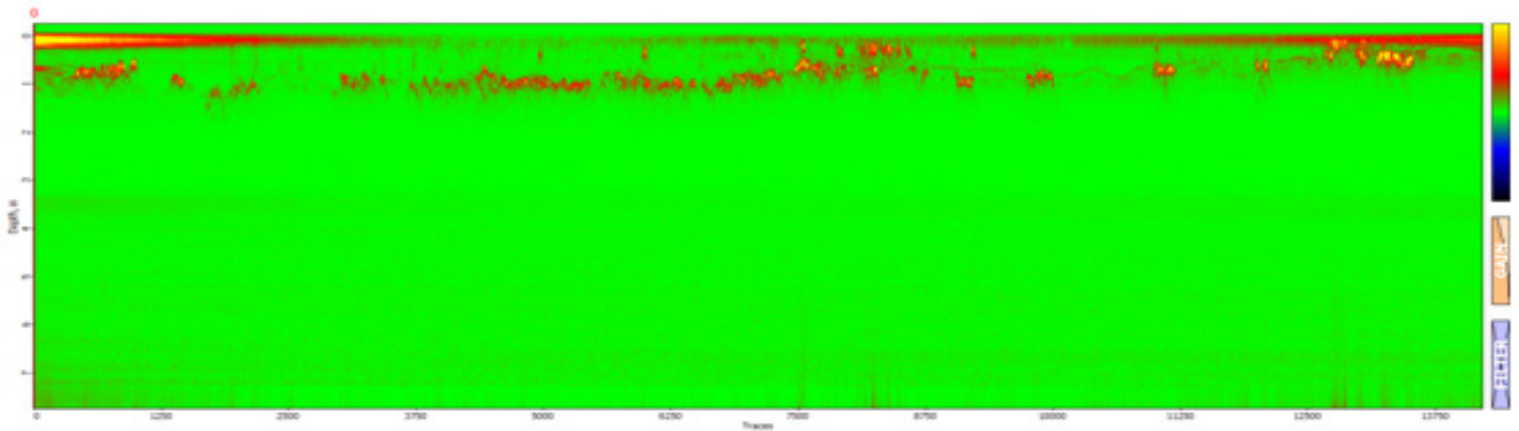

Fig. 8. Processed GPR profile obtained by geophysical survey with $500 \mathrm{MHz}$ antennae from the inflatable boat along the transect No.3 in lake Zeiḷu

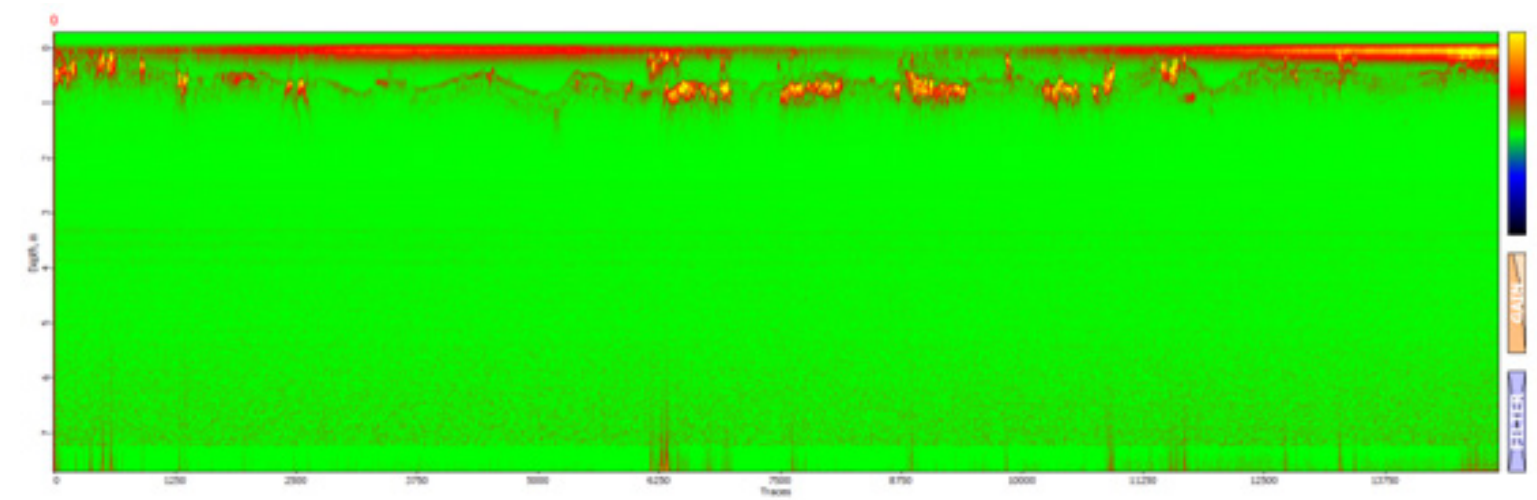

Fig. 9. Processed GPR profile obtained by geophysical survey with $500 \mathrm{MHz}$ antennae from the inflatable boat along the transect No.4 in lake Zeiliu

GPR is a non-invasive and non-destructive, attenuation, causing a reduction in depth penetration. environmentally safe technique for high-resolution Issac and MacCulloch conclude, that $25 \mathrm{MHz}, 100 \mathrm{MHz}$ geophysical mapping of the near-surface structure of sediment layers. It has many applications, including groundwater and mineral exploration, archaeological and forensic investigations and depth soundings through ice or water. The source for GPR data is a high-frequency (10 $-1000 \mathrm{MHz}$ ) electromagnetic pulse which is transmitted into the ground at regular intervals along a survey line. This pulse is reflected back to the surface at subsurface boundaries where electrical properties change. In low conductivity materials such as sands, gravels and bedrock, GPR can sound to depths of $50 \mathrm{~m}$, in general, GPR works well to a depth of about $25 \mathrm{~m}$. Speaking about fresh water, it has relatively low attenuation, however, the presence of suspended sediments in the water can increase and $200 \mathrm{MHz}$ antennas image the bottom of the lake very well to about $12-15 \mathrm{~m}, 8 \mathrm{~m}$ and $7 \mathrm{~m}$, respectively [5]. GPR was applied for mapping sediments and topography of Latvian lakes Engure and Pape using the similar equipment - Zond-12e GPR Advanced [3]. Purmalis et al. [3] conclude that high content of mineral compounds (also clays) and minor differences among layers in Pape Lake causes problem to analyse and even see the GPR signal. Most of the signal dissipates in sediments and deeper layers cannot be seen. Problems of permittivity in that kind of material correspond to results in literature, where is suggested that GPR is not a viable choice for surveying in clay rich areas where $5-10 \%$ clay content can reduce penetration depth to less than $1 \mathrm{~m}$ [16]. 


\section{Conclusions}

None of applied GPR antenna systems $(500 \mathrm{MHz}, 300$ $\mathrm{MHz}, 75 \mathrm{MHz}$ ) have provided sufficient geophysical data to detect clay in the lakebed of Zeilu. The factors, which limit using GPR for this purpose in lake Zeiļu, could be high density of submerged and underwater macrophytes, high concentration of suspended sediments in water and thick double-layered ice cover in winter. Therefore, the recommended method to detect clay and its layer thickness is the conventional method - the analysis of geological core samples, but the completed study opens new research directions. The combination of sonar and GPR survey can be applied as well. Considering the property of clay to absorb transmitted GRP signals, the absence of reflections from the lake bottom can be used as an indirect indicator, which specifies possible presence of clay deposits at the lake bottom.

\section{REFERENCES}

[1] $\bar{E}$. Aleksejevs, J. Birzaks, "The current status of coregonidae in the lakes of Latvia," Acta Biol. Univ. Daugavp., vol. 3, pp. 3 - 13, 2012.

[2] R. Tretjakova, S. M. Misiņa, J. Lukašenoks, "Chemical and Biological Properties of the Lake Blue Clay," Environment. Technology. Resources, Proceedings of the 11th International Scientific and Practical Conference, vol. I, pp. 290-295, 2017.

[3] O. Purmalis, A. Alksnis, J.Taskovs, J. Burlakovs, "Ground-penetrating radar (GPR) screening in shallow Engure and Pape lagoon lakes," Research for Rural Development, vol.1, pp. 228-235, 2016.

[4] G.S. Baker, T.E. Jordan, J. Talley, "An introduction to ground penetrating radar (GPR)”, in G.S. Baker, H.M. Jol, eds., Stratigraphic Analyses Using GPR: Geological Society of America Special Paper 432, pp. 1-18, 2007. [Online]. Available from: https://www. researchgate.net/publication/279869961_An_introduction_to ground penetrating radar GPR [Accessed Jan 23, 2019].

[5] H. Isaac, G. MacCulloch, "Adventures with GPR experiments through ice," Recorder, vol. 29, no. 2, 2004. [Online]. Available: https://csegrecorder.com/articles/view/adventures-with-gpr-experiments-through-ice
[6] T. MacFarlane, J.R. Ferguson, "Evaluation of Ice-Coupled and Elevated GPR Antenna Acquisition on Ice CREWES Research Report", vol. 22, 2010. [Online]. Available: https://www.crewes. org/ForOurSponsors/ResearchReports/2010/CRR201059.pdf

[7] B. J. Moorman, F. A. Michel, "Bathymetric mapping and sub-bottom profiling through lake ice with ground-penetrating radar," Journal of Paleolimnology, vol. 18, pp. 61-73, 1997.

[8] W.S.L. Banks, C.D. Johnson, "Collection, processing, and interpretation of ground-penetrating radar data to determine sediment thickness at selected locations in Deep Creek Lake, Garrett County, Maryland 2007," U.S. Geological Survey Scientific Investigations Report 2011-5223, 36 p., 2011. [Online]. Available: https:// pubs.usgs.gov/sir/2011/5223/pdf/sir2011-5223.pdf

[9] A.S. Hickin, B. Kerr, T.E. Barchyn, R.C. Paulen, "Ground penetrating radar and capacitively coupled resistivity to investigate fluvial architecture and grain-size distribution of a gravel floodplain in Northeast British Columbia, Canada," Journal of Sedimentary Research, vol. 79, pp. 457-477, 2009.

[10] J. Burlakovs, O. Purmalis, M. Krievans, Y. Jani, "Ground-penetrating radar (GPR) geoenvironmental screening in lakes of Latvia: challenges and outcomes" In: Proceedings of Near Surface Geoscience, Barcelona, EarthDoc, EAGE, We 22P1 14, 2016.

[11] R.F. Leclerc, E.J. Hickin, "The internal structure of scrolled floodplain deposits based on ground penetrating radar, North Thompson River, British Columbia," Geomorphology, vol. 21, pp. 17-38, 1997.

[12] M. Słowik, "Analysis of fluvial, lacustrine and anthropogenic landforms by means of ground-penetrating radar (GPR): field experiment," Near Surface Geophysics, vol.12, pp.777-791, 2014.

[13] J.S. Mellett, "Profiling of ponds and bogs using ground-penetrating radar," Journal of Paleolimnology, vol 14, pp. 233-240, 1995.

[14] Database (Datu bāze). [Online]. Available: https://www.ezeri.lv/ database/2363/ Nature of Latvia (Latvijas daba). 6.sēj. Rīga: Latvijas enciklopēdija, 1998. (in Latvian).

[15] G. J. Schwamborn, J.K. Dix, J. M. Bull, V. Rachold, "High-resolution Seismic and Ground Penetrating Radar - Geophysical Profiling of a Thermokarst Lake in the Western Lena Delta, Northern Siberia," Permafrost and Periglacial Processes, vol. 13, pp. 259269, 2002.

[16] J. Karušs, V. Seglinšš, D. Pipira, "Analysis of GPR signals in clayey soils," ("Mālainās gruntīs iegūto radiolokācijas signālu analīze,") Material Science and Applied Chemistry, vol. 26, pp.

$$
\text { 21-27, 2012. (in Latvian). }
$$

\section{ACKNOWLEDGMENTS}

European Regional Development Fund Postdoctoral research aid Nr.1.1.1.2/16/I/001 research application "Identification of blue clay in lakes of Latgale region and possibilities of its application, Nr.1.1.1.2/VIAA/1/16/131".
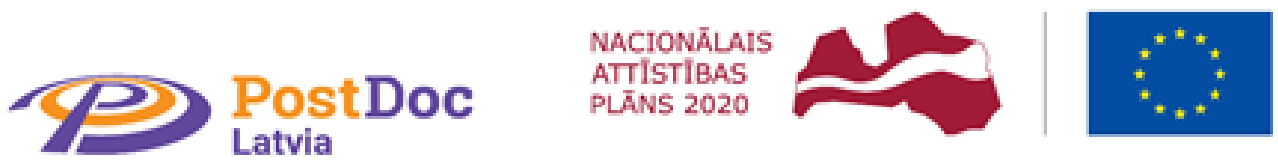

EIROPAS SAVIENĪBA

Eiropas Regionălăs attisitibas fonds 